\title{
EFFECTS OF WORK-RELATED STRESSORS AND WORK ENGAGEMENT ON WORK STRESS: HEALTHCARE MANAGERS' PERSPECTIVE
}

Aydin, I.

Ipek Aydin / Dokuz Eylul University, Faculty of Sport Sciences, Department of Recreation, Turabiye Mah. Beyler Cad. No:4 Seferihisar / Izmir, Turkey.Email: ipek.aydin@deu.edu.tr

\begin{abstract}
This study identified the effects of Work-Related Stressors (WRSs) and Work Engagement (WE) on managers' Work Stress (WS). Data were collected from 109 healthcare managers (HMs) from public and private hospitals in İzmir, Turkey, using a structured questionnaire. Exploratory factor analyses were carried out to determine the construct validity of the WRS, WE, and WS scales. Two WRS factors were identified, Support and Control (SC), and Responsibility and Relationship (RR), and one factor each for the WE and WS scales. Correlation analyses indicated a significant positive relationship between the WRS factors and a negative relationship between WE and the other variables. Hierarchical regression analyses were conducted to evaluate the effects on WS of HM demographic variables, WRS dimensions, and WE. The first step showed that age and managerial experience affects WS. The second step showed that RR had a significant positive effect on WS, whereas SC had no effect. Additionally, WE significantly decreased WS.

Implications for Central European audience: The findings suggest that HMs can reduce WS by focusing on RR. In addition, HM willingness, enthusiasm, physical and mental fitness, and effort to achieve goals all affect their WS. Thus, HMs' perceptions of WE may reduce their perceptions of WS. Managers, therefore, need to consider job satisfaction, which is particularly associated with work stress, to increase WE. Managers should consider their needs and expectations both formally and informally by holding regular evaluations to listen to their employees' voices.
\end{abstract}

Keywords: work-related stressors; work engagement; work stress; healthcare managers; hospitals

JEL Classification: 110, J81

\section{Introduction}

Today, healthcare organisations are characterised by a dynamic organisational structure, rapid change, technological developments, and risks and uncertainties in treatment processes that lead to rising stress. Stress levels have thus increased because of environmental (external), organisational (external) and individual (internal) reasons. Most importantly, growing competition between organisations (Dhawan, 2013), more complex 
organisational structures, change, and the organisations' resulting socio-economic complexity are external reasons for rising stress levels. The intensity of competition, high workloads, and interpersonal relationships are individual causes of stress.

Healthcare professionals are exposed to physical, psychological, and social stress (Frenk et al., 2010). Physical stress factors include prolonged standing, heavy lifting (Morse et al., 2008), and sleep deprivation. Psychological risk factors include excessive employee responsibilities (Weigl et al., 2012), the risks and uncertainties of healthcare service (Bochatay et al., 2017), and the quality of care of and communication with patients. Social stress factors include relationships with co-workers and imbalance between working and family life. In addition, stress factors like patients' anxiety (Cockburn \& Pit, 1997; Matthys et al., 2009); and workplace violence caused by patients or relatives (Cannavò et al., 2019) should not be ignored. These workplace stressors have a significant impact on healthcare workers' health (Taouk et al., 2020).

The well-being of healthcare workers has become a prominent topic recently, particularly in relation to perceived stress. Working life is often characterised as stressful and harmful to health, especially in healthcare organisations (Wallace et al., 2009). Previous studies have demonstrated a relationship between healthcare workers' psychological well-being and job stress (Holman et al., 2018). However, perceived job stress has no significant effect on healthcare service quality, no matter how stressed healthcare workers are (Aydin \& Özmutaf, 2020). In this study, we, therefore, investigated whether workplace stressors really affect healthcare workers' perceived stress. Specifically, we evaluated the effects on perceived work stress of work engagement, which is related to working selflessly and being mentally and physically alert at work.

\section{Literature review}

\subsection{Work stress and work-related stressors}

Stress can be caused by external factors, such as family life, work environment, and social life, as well as internal reasons related to illness or medical processes. Stress is an individual's reaction to a variety of situations perceived as threatening (Sutherland \& Cooper, 1990) and the emotional and physical reactions of individuals to stressors (pressure, demands, and changes in their environment). Stress, which is often regarded as an experience caused by pressures or demands on an individual, is considered an epidemic (Blaug et al., 2007).

Work stress can be defined as negative physical and emotional psychological reactions resulting from an individual's inability to fulfil their expected roles and duties (Antonova, 2016) While some researchers have supported a risk assessment approach to managing work-related stress (Cox et al., 2003; Cox \& Cox, 1993), others have questioned its effectiveness due to difficulties in identifying psychological harms and dangers (Rick \& Briner, 2000).

Stressors are situations that can lead to strain in the work-related environment (Kahn et al., 1992). Although some assume that sudden organisational changes or traumatic events cause stress, most stressors result from general working conditions rather than sudden changes (Ford et al., 2014). Responsibilities and duties that require mental or physical 
resources create stress if they require continuous effort without enough time (Demerouti \& Bakker, 2011).

Stressors can be categorised as related to environmental, organisational, and individual resources. Environmental stressors include changes in socio-cultural life, economic life, technology, and legal and political life. Organisational stressors include poor organisational commitment, low performance, employee turnover, work absenteeism, and occupational accidents. Numerous studies have shown the negative effects of organisational stressors on physical health (Fishta \& Backé, 2015; Huang et al., 2015) and mental health (Stansfeld $\&$ Candy, 2006). Other research has demonstrated the relationship between the quality of work conditions and well-being. Specifically, poor quality work conditions (Fishta \& Backé, 2015), such as job insecurity, low job control, high job demands, and effort-reward imbalance, all reduce well-being (Nyberg et al., 2014; Stansfeld \& Candy, 2006) High job demands and low job control may cause stress-related ill health (Karasek \& Theorell, 1990) Individual stressors are generally related to effects on the mental, physical and social health of the individual.

Both organisational and individual characteristics contribute significantly to occupational health and work stress (Shaw et al., 1992). For example, an extroverted personality or optimism both relieve stress, although this mitigating effect of personality is not the best method to prevent work stress (Paunonen \& Ashton, 2001). In particular, a deterioration in the quality of work-life and work stress are related to negative mental and physical health outcomes and low job satisfaction (Mark \& Smith, 2012).

In general, although health institutions cannot eliminate environmental stress factors, they can view them as either threats or opportunities. Mackay et al. (2008) defined a workrelated stressors taxonomy with six specific stressors: demand, support, control, role, workplace relationships, and organisational change. In healthcare, work stress can directly affect service delivery in that the treatment, care, or support services offered by the employee may be adversely affected due to occupational factors, such as excessive workload, long working hours, an uneasy working environment, lack of job security, or stress factors in their own personal and social life. Stress can cause financial and, more importantly, moral losses in the health sector due to its uniquely high sensitivity to errors and uncertainties. Thus, it is critical to identify and eliminate or minimise the factors that cause stress in health services.

\subsection{Work Engagement}

Work engagement is a desirable situation for any business. It is particularly important in healthcare, given the psychological dimension of the service provided. Unlike in the business that produces a standard product, healthcare workers should also be concerned with each patient's physiological and psychological condition. Therefore, healthcare services should be delivered with devotion, not only rationally.

Work engagement is enthusiasm to do the job and feeling proud of the work. It affects purposeful behaviours, requires a high level of mobility, provides sustainability to achieve goals, and increases intrinsic motivation. Ashforth and Humphrey (1995) conceptualise work engagement as a tool that motivates employees to work in a coordinated manner with 
hands, minds, and hearts. It means that employees make an effort in their job, not only to earn money or finish the job but self-selflessly and conscientiously.

Work engagement has three basic dimensions: vigour, dedication, and absorption (W. B. Schaufeli et al., 2002). Vigour means behaving energetically; dedication means showing emotional commitment; absorption means being cognitively engaged. Vigour refers to the individual's high physical and mental energy in working life, demonstrated by making an effort while performing job activities and having the power to cope with difficulties. Dedication refers to the individual's feelings about their job, such as the importance they attach to the job, enthusiastic performance, and pride in the work. Absorption means that the individual concentrates completely on work and deals with the job deeply. The individual does not notice time passing while at work and has difficulty leaving the job to return to social life. An individual's intrinsic motivation, attitudes, and thoughts about work affect work commitment and performance (Schaufeli \& Salanova, 2007).

Given its impact on organisational success, numerous studies have been conducted on work engagement in the last 20 years (Bailey et al., 2017). Work engagement and burnout can be considered as opposite concepts (Fiabane et al., 2013). Work engagement increases an employee's commitment to the organisation (Abeer, 2017). Increasing employee loyalty (Christian et al., 2011) provides social support and autonomy and makes employees feel good at their jobs, such as increasing their level of well-being and seeing their work as a part of themselves. However, there is also a relationship between engagement and factors affecting workers' well-being, such as burnout (Bezuidenhout \& Cilliers, 2010), job performance (Mauno et al., 2007), job satisfaction (Christian et al., 2011), and organisational commitment (Macey \& Schneider, 2008).

In the scope of the theoretical framework, this study aimed to determine the effects of workrelated stressors (WRSs) and Work Engagement (WE) on Work Stress (WS) among managers. The basic research model is shown in Figure 1.

\section{Figure 1 | Research Model}

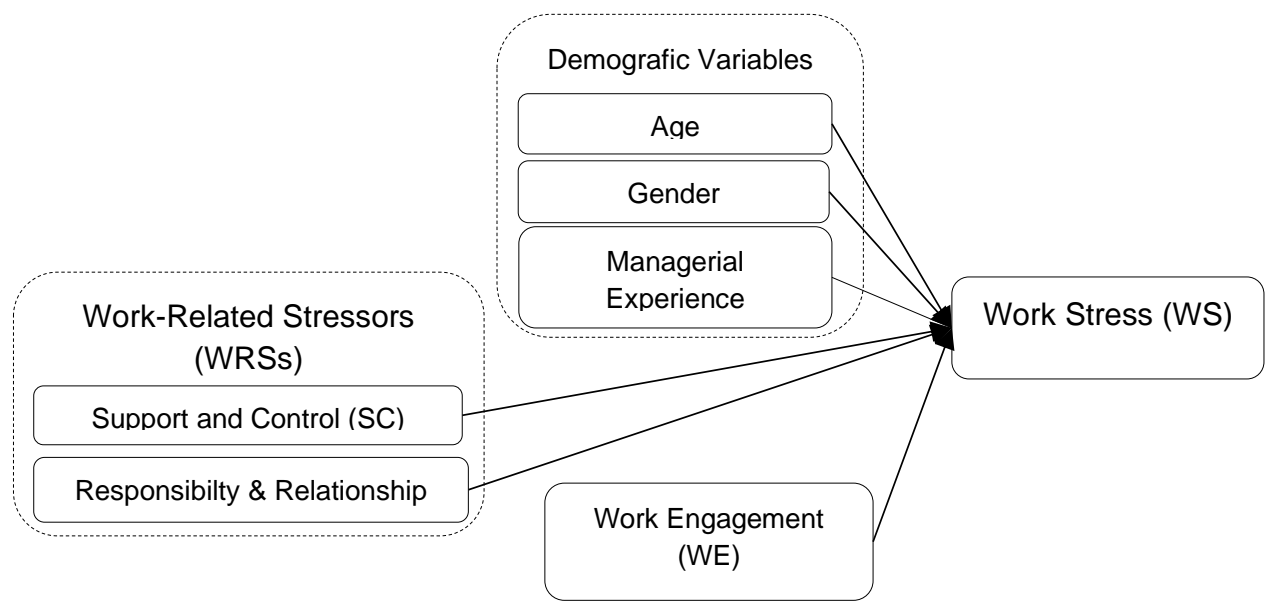

Source: author 
Based on this research model, the study tested the following hypotheses:

$\mathrm{H}_{1}$ : There is a significant correlation between WRSs, WE, and WS.

$\mathrm{H}_{2}$ : Demographic variables have a significant effect on WS.

$\mathrm{H}_{2 \mathrm{a}}$ : Age has a significant effect on WS.

$\mathrm{H}_{2 b}$ : Gender has a significant effect on WS.

$\mathrm{H}_{2 c}$ : Managerial experience has a significant effect on WS.

$\mathrm{H}_{3}$ : WRSs have a significant effect on WS.

$\mathrm{H}_{3 a}$ : Support and control have a significant effect on WS.

$\mathrm{H}_{3 \mathrm{~b}}$ : Responsibility and relationship have a significant effect on WS.

$\mathrm{H}_{4}$ : WE has a significant negative effect on WS.

\section{Research methodology}

\subsection{Sample}

The present study aimed to evaluate the effects of WRSs and WE on WS among healthcare managers (HMs). The study was carried out between February 2019 and June 2019. The study's universe comprised HMs (medical, administrative, nursing, and quality managers) in Izmir, Turkey working in public hospitals, university hospitals, and private hospitals. The surveys were conducted by e-mail and completed online. Out of 441 e-mails sent to HMs, 189 were sent to public hospital managers, 62 to university hospital managers, and 190 were sent to private hospital managers. In total, 108 surveys were completed.

\subsection{Measures}

Data were obtained from the HMs online using a structured questionnaire of 4 parts with 22 items and four questions. The questionnaire consists of the Work Engagement scale, WorkRelated Stressors scale, Work Stress scale and demographic questions about the HMs.

Work Engagement Scale: The work Engagement scale consists of 9 items from Balducci et al. (2010), adapted for healthcare services. The scale items were rated on a seven-point scale varying from 0 (never) to 6 (always).

Work-Related Stressors Scale: Work-Related Stressors scale consist of 8 items, adapted from Cousins et al. (2004). These items were rated on a five-point scale Likert-type (5 = strongly agree; 1 = strongly disagree).

Work Stress Scale: The work Stress scale consists of 5 items, adapted from Lambert et al. (2006). The items were measured using a five-point Likert-type ( $5=$ strongly agree; $1=$ strongly disagree). 


\subsection{Data analysis}

After scanning, eligible surveys for the analysis were computerised. An IBM SPSS 22 statistical program was used for data analysis. Exploratory factor analysis was conducted to assess the construct validity of the research variables (WRS dimensions, WE, and WS). The reliability of all scales and subscales were assessed using Cronbach's alpha. Correlation analyses were conducted to determine the direction and strength of the relationships between the research variables. Finally, stepwise regression analysis was conducted to determine the effects of the independent variables on the dependent variable. A p-value equal to or less than 0.05 was accepted as statistically significant.

\section{Results}

Table 1 summarises the participants' socio-demographic characteristics. The mean age of the $108 \mathrm{HMs}$ was 40.96 (SD=7.99) years, of whom $49.1 \%$ were female, and $50.9 \%$ were male. About $13.5 \%$ were medical managers, $47.9 \%$ were administrative managers, and $38.5 \%$ were nursing managers. The mean managerial experience was seven years and six months ( $\mathrm{SD}=6.51$ years).

Table 1 | Socio-demographic Characteristics of HWs

\begin{tabular}{llll}
\hline & & $\mathrm{N}$ & $\%$ \\
\hline \multirow{2}{*}{ Gender $(\mathrm{n}=\mathbf{1 0 8})$} & Female & 53 & 49.1 \\
& Male & 55 & $\mathbf{5 0 . 9}$ \\
\hline \multirow{2}{*}{ Position $(\mathrm{n}=96)$} & Medical & $\mathbf{1 3}$ & $\mathbf{1 3 . 5}$ \\
& Administrative & 46 & 47.9 \\
& Nursing & $\mathbf{3 7}$ & $\mathbf{3 8 . 5}$ \\
\hline Age & Mean \pm SD & $40.96 \pm 7.99$ & \\
\hline Managerial Experience & Mean \pm SD & $7.51 \pm 6.51$ & \\
\hline
\end{tabular}

Source: authors

Reliability tests were conducted on the research variables data set, and Cronbach's alpha value was found within acceptable limits (Nunnally, 1967). The exploratory factor analysis was performed using principal component analysis with varimax rotation. Based on the scree plot dispersion, factors with Eigenvalues (main value) greater than one were considered. For the WRS scale, the pattern matrix of the principal component factor analysis with Kaiser Normalization identified two factors accounting for $57.35 \%$ of the total variance. Each was labelled according to its common characteristics (Table 2). All items loaded on their respective factors with loadings greater than 0.5 . The Bartlett test result was $244.24(p<0.001)$, while the Kaiser-Meyer-Olkin illustration value was 0.81 . Each factor was labelled according to its common characteristics (Table 2). The two factors were support and control (Factor 1) and responsibility and relationships (Factor 2). Reliability tests were conducted on the WRS data based on derivative statistics, yielding an overall Cronbach's alpha value of $0.82(p<0.001)$. 


\begin{tabular}{|c|c|c|c|c|c|}
\hline Work-Related Stressors (WRSs) & 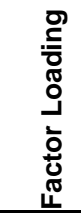 & 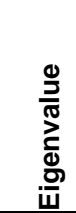 & 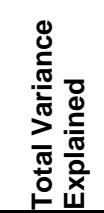 & $\frac{\mathbb{2}}{\frac{2}{2}}$ & $\begin{array}{l}\text { ] } \\
\sum^{\mathbb{\Phi}}\end{array}$ \\
\hline Support and Control (Factor 1) & & 3.52 & 40.04 & $.74^{*}$ & 2.82 \\
\hline My line manager encourages me at work & .769 & & & & \\
\hline I have a choice in deciding what I do at work? & .751 & & & & \\
\hline I receive the respect I deserve from my colleagues at work & .704 & & & & \\
\hline Staff are consulted about change at work & .581 & & & & \\
\hline Responsibility and Relationships (Factor 2) & & 1.07 & 13.31 & $.71^{\star *}$ & 2.77 \\
\hline I have unrealistic time pressures & .843 & & & & \\
\hline I am subject to bullying at work & .736 & & & & \\
\hline I am clear what my duties and responsibilities are & .540 & & & & \\
\hline Relationships at work are strained & .509 & & & & \\
\hline
\end{tabular}

$\mathrm{KMO}=0.81^{*}$; Bartlett's Test of Sphericity $=244.24$; Total Variance Explained: $57.35 \%$; Cronbach's

Alpha $=0.82^{*} ;{ }^{*} \mathrm{p}<0.001 ;{ }^{* *} \mathrm{p}<0.05$

Source: authors

For the WE scale, the pattern matrix of the principal component factor analysis with Kaiser Normalization identified one factor (Table 3) that accounted for $85.39 \%$ of the total variance. All items had factor loadings greater than 0.4. The Bartlett test result was 496.10 $(p<0.001$ level), while the Kaiser-Meyer-Olkin illustration value was 0.88 . Reliability tests were applied to the WE data based on derivative statistics. The overall Cronbach's alpha value was $0.96(p<0.001$.

Table 3 | Factor Analysis Results (Work Engagement)

\begin{tabular}{|c|c|c|c|c|c|}
\hline & 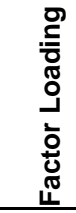 & 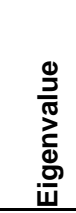 & 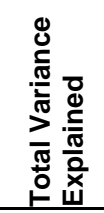 & $\frac{\pi}{\frac{\pi}{2}}$ & $\sum_{\mathbb{\Phi}}^{\infty}$ \\
\hline Work Engagement (WE) & & 4.80 & 60.00 & $.90^{*}$ & 3.86 \\
\hline I am enthusiastic about my job & .871 & & & & \\
\hline When I get up in the morning, I feel like going to work & .851 & & & & \\
\hline At my work, I feel bursting with energy & .843 & & & & \\
\hline I feel happy when I am working intensely & .831 & & & & \\
\hline My job inspires me & .825 & & & & \\
\hline At my job, I feel strong and vigorous & .738 & & & & \\
\hline I am proud of the work that I do & .706 & & & & \\
\hline I get carried away when I am working & .432 & & & & \\
\hline $\begin{array}{l}\mathrm{KMO}=0.88^{*} ; \text { Bartlett's Test of Sphericity }=496.10 ; \\
\text { alpha }=0.90^{*} ;{ }^{*} p<0.001\end{array}$ & Var & & & & \\
\hline
\end{tabular}

For the WS scale, the pattern matrix of the principal component factor analysis with Kaiser Normalization identified one factor (Table 4) that accounted for $63.16 \%$ of the total variance. All items had factor loadings greater than 0.7 . The Bartlett test result was 253.55 
$(p<0.001$ level), while the Kaiser-Meyer-Olkin illustration value was 0.80 . Reliability tests were applied to the WS data based on derivative statistics. The overall Cronbach's alpha value was $0.85(p<0.001)$.

Table 4 | Factor Analysis Results (Work Stress)

\begin{tabular}{|c|c|c|c|c|c|}
\hline & 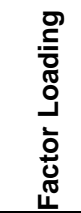 & 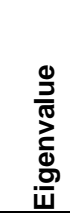 & 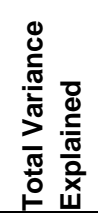 & $\frac{\text { 몽 }}{\frac{2}{2}}$ & 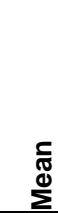 \\
\hline Work Stress (WS) & & 3.16 & 63.16 & $.85^{*}$ & $2 . \overline{51}$ \\
\hline When I'm at work I often feel tense or uptight & .927 & & & & \\
\hline I am usually under a lot of pressure when I am at work & .851 & & & & \\
\hline A lot of time my job makes me very frustrated or angry & .763 & & & & \\
\hline There are a lot of aspects of my job that make me upset & .709 & & & & \\
\hline I am usually calm and at ease when I'm working & .701 & & & & \\
\hline $\begin{array}{l}\mathrm{KMO}=0.80^{*} ; \text { Bartlett's Test of Sphericity }=253.55 \text {; Tota } \\
\text { alpha }=0.85^{*} ;{ }^{*} \mathrm{p}<0.001\end{array}$ & ance & Expla & 6 & $\bar{C}$ & ch's \\
\hline
\end{tabular}

Table 5 presents the correlations between WS, WRS dimensions, and WE. WS and the two WRS dimensions had a strong positive relationship between themselves $(r=0.53$ to $0.62)$, while WS was strongly negatively correlated with the WRS dimensions and WE ( $r=-$ 0.66 to -0.48$)$.

Table 5 | Correlation Matrix

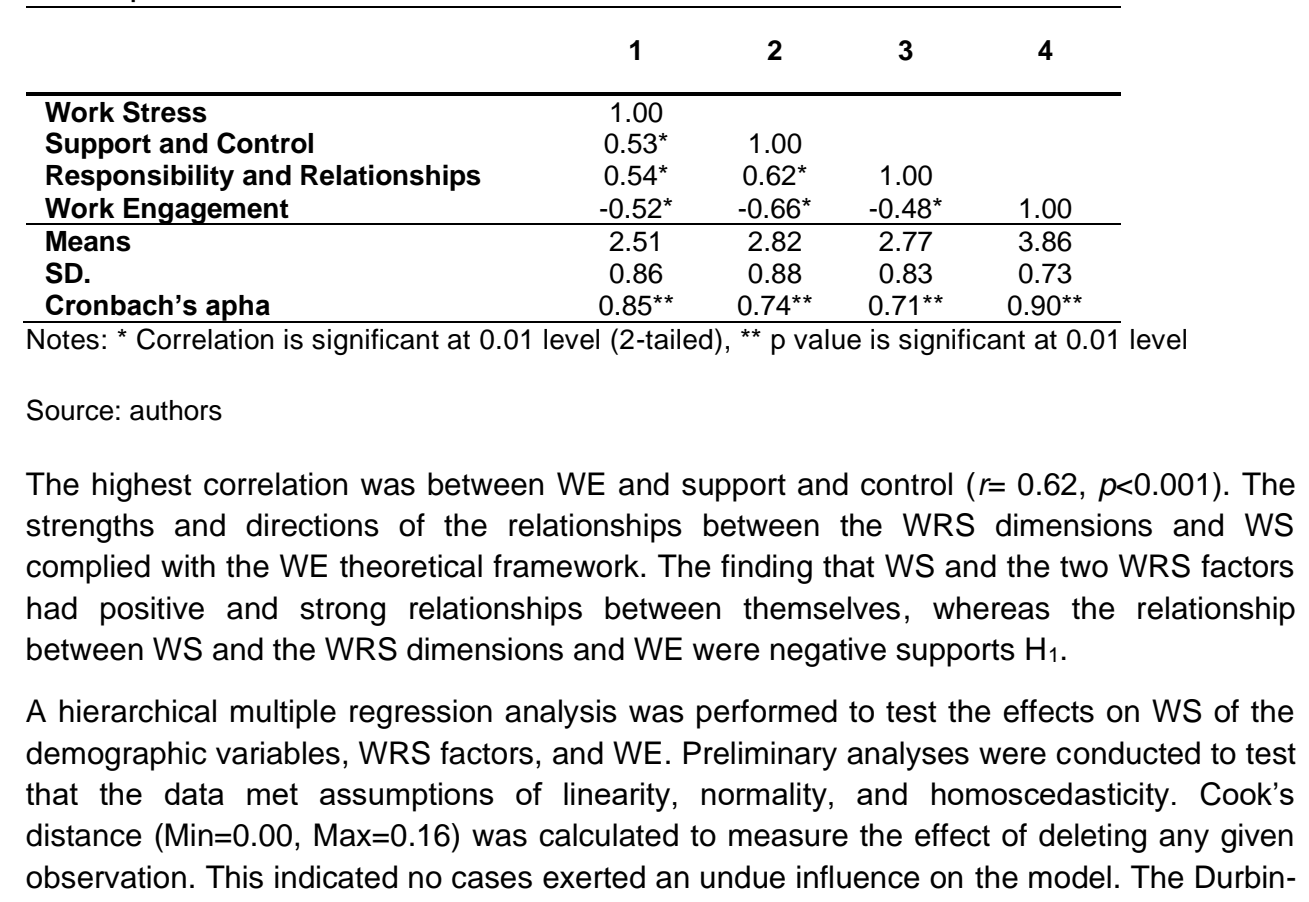


Watson statistic was computed to test for autocorrelation in the residuals from the regression analysis. Its value was 2.31 , which is considered acceptable.

In the first step of the hierarchical multiple regression, three predictors were entered: gender, age, and managerial experience. This model was statistically significant $F(96,3)=$ $3.57 ; p<0.001$ and explained $8 \%$ of the variance in WS (Table 6). Regarding the importance of the Beta values, only age $(\beta=0.22 ; p=0.045)$ and managerial experience $(\beta=-0.26$; $\mathrm{p}=0.018$ ) both significantly determined WS. This supported $\mathrm{H}_{2 a}$ and $\mathrm{H}_{2 c}$ but not $\mathrm{H}_{2 b}$.

After entering the two WRS factors and WE in step two, the total variance explained by the model was $49 \%(F(6,96)=14.112 ; \mathrm{p}<0.001)$. After controlling for the two WRS factors and WE, the introduction of the two WRS factors and WE explained an additional $41 \%$ variance in WS $\left(R^{2}\right.$ change=0.41). In the final model, age, responsibility and relationship, and WE were statistically significant predictors of WE. Responsibility and relationship had the highest Beta value $(\beta=0.39 ; p<0.001)$. Age was also a significant positive determiner $(\beta$ $=0.23 ; p=0.02)$, whereas WE was a significant negative determiner $(\beta=-0.31 ; p<0.05)$. Thus, these hierarchical multiple regression findings support $\mathrm{H}_{3 b}$ and $\mathrm{H}_{4}$.

Table 6 | Hierarchical Regression Analysis of the Effects on WS of Gender, Age, and Managerial Experience, WRS Factors and WE

\begin{tabular}{|c|c|c|c|c|c|c|}
\hline & $\mathbf{R}$ & $\mathbf{R} 2$ & $\begin{array}{c}\mathbf{R}^{2} \\
\text { Change }\end{array}$ & $\beta$ & $\mathbf{t}$ & $95 \% \mathrm{Cl}$ \\
\hline Step 1 & ,28 &, $08^{*}$ & & & & \\
\hline Age & & & & $.219^{\star}$ & 2.035 & {$[0.00 .0 .05]$} \\
\hline Gender & & & & -.055 & -.549 & {$[-0.44 \cdot 0.25]$} \\
\hline Managerial Experience & & & & $-.259^{*}$ & -2.403 & {$[-0.06 .-0.01]$} \\
\hline Constant & & & & 1.880 & 3.546 & [0.83. 2.93] \\
\hline Step 2 & ,70 & $49^{*}$ &, $41^{*}$ & & & \\
\hline Age & & & & .226 & 2.743 & {$[0.01 .0 .04]$} \\
\hline Gender & & & & -.046 & -.610 & {$[-0.34 \cdot 0.18]$} \\
\hline Managerial Experience & & & & -.155 & -1.860 & {$[-0.04,0.00]$} \\
\hline Support and Control & & & & .068 & .592 & {$[-0.16 .0 .29]$} \\
\hline Responsibility and Relationships & & & & $.391^{* *}$ & 3.988 & {$[0.21 .0 .62]$} \\
\hline Work Engagement & & & & $-.311^{*}$ & -3.136 & {$[-0.61,-0.14]$} \\
\hline Constant & & & & 1.812 & 2.339 & {$[0.27 .3 .35]$} \\
\hline
\end{tabular}

\section{Discussion}

This aimed to determine the effects on work stress of two work-related stressors dimensions (support and control; and responsibility and relationships) and work engagement. After testing the validity and reliability of the scales, correlation and regression analyses were conducted on these variables. Stressors were predicted to have a negative relationship with work stress and work engagement, while work engagement was predicted to reduce work stress. Previous research shows that stressors increase work stress (Keashly et al., 1997) and reduce well-being (Fortes-Ferreira et al., 2006; van Bogaert et al., 2014), whereas work engagement reduces work stress (Fiabane et al., 2013). 
The hierarchical regression analysis indicated that only the age, gender, and managerial experience of the HMs were included in the first step. The first step showed that age increased whereas managerial experience reduced HM work stress.

\section{Figure 2 | Regression Results (Second Step)}

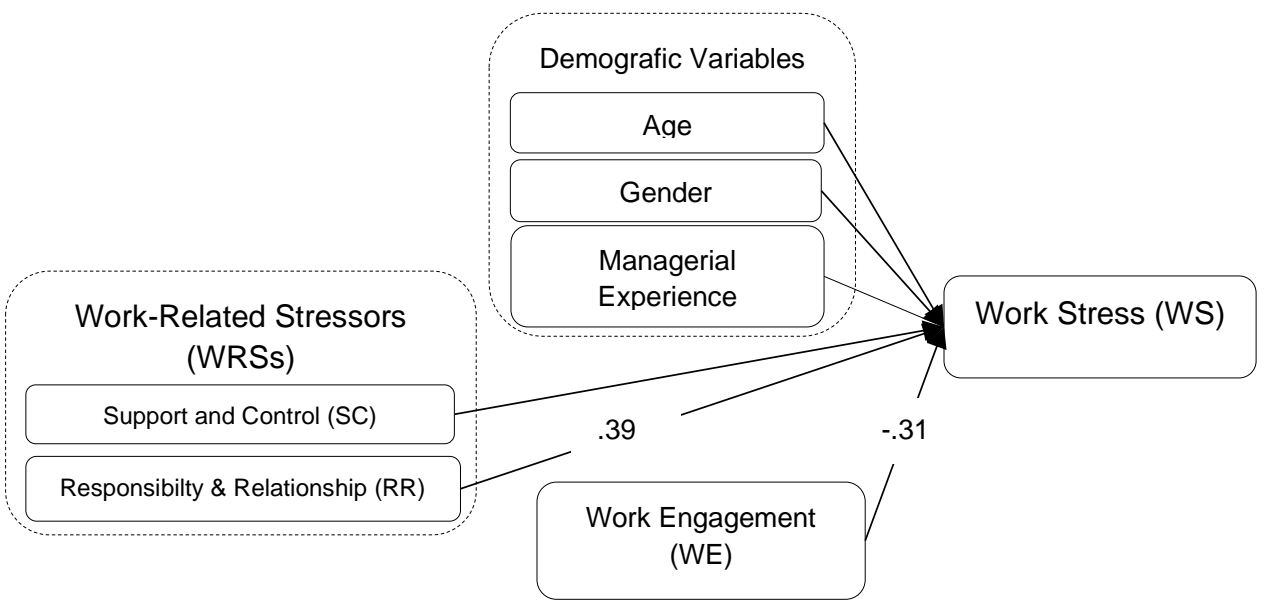

Source: authors

In the second step of the hierarchical regression analysis, the two work-related stressors factors (support and control, and responsibilities and relationships) and work engagement were added to the research model. Whereas responsibilities and relationships had a positive effect on work stress, support and control had no significant effect. That is, although HMs work in stressful work environments, their perceived job stress does not affect the service quality they offer (Aydin \& Özmutaf, 2020).

Likewise, not all the stressors affected work stress. This may be because managers have too many responsibilities and have to manage relationships. The optimum level of responsibility may improve the motivation and general well-being of the healthcare leaders (van Dorssen-Boog et al., 2020), but increasing responsibility (Crawford et al., 2010); and complexity of the relations (Tutuncu et al., 2014) may increase the work stress. Moreover, according to the job demand model (Karasek, 1979), it is assumed that if HWs are facilitated with more autonomy in their work, they will be able to handle their jobs better (Laschinger et al., 2001). From the view of the HWs the external control may cause pressure while they are working, and the absence of external control allows HWs to complete their tasks in their own favourite way. According to research results, support and control had no significant effect, but they are the main functions of management as well. Therefore managers should provide support and control, and they may think that they have fulfilled these duties, their effects on perceived stress may not be determined.

Another important finding from the second step is that work engagement reduces work stress. Work engagement leads to increased well-being and positive organisational outcomes. In support of this interpretation, work engagement contributes to proactive stress coping (Unsworth \& Mason, 2012; van Dorssen-Boog et al., 2020) from the view of the 
HWs. Work engagement optimises stressful job demands such as role ambiguity, conflict (Cavanaugh et al., 2000) and work engagement is important in view of stress prevention (van der Elst et al., 2016). This may be because of the unique characteristics of the health sector.

Managers should consider their needs and expectations both formally and informally by holding regular evaluations to listen to their employees' voices (Knight et al., 2017) That is, work engagement improves mental and physical health (Bakker \& Demerouti, 2017) and increases job performance, which in turn is related to job stress. In addition, behaviours such as absenteeism and leaving the job, which is related to job stress, are also related to work engagement (Bakker \& Demerouti, 2017; Timms et al., 2015) t (Bakker \& Demerouti, 2017; Timms et al., 2015) Inoue (2014) determined that occupational stress factors are related to work engagement in Japan. Accordingly, it can be said that work stress may decrease if work engagement increases. Finally, the present study showed that age and managerial experience had a significant effect on work stress in the first but not the second step.

\section{Conclusion}

The most important feature of this article is that it reflects the views of HMs and, especially recently, increasing importance given to work engagement and work stress. Work engagement is associated with many of the concepts of work-related well-being. It is directly proportional to organisational goals, such as increasing organisational commitment and job satisfaction. However, many studies indicate that there is a negative relationship between work stress and job-related well-being concepts. Our study, therefore, evaluated the effects on work stress of work-related stressors and work engagement. Work-related stressors were measured in two dimensions thought to be positively associated with job stress: support and control and responsibilities and relationships. However, our findings indicated that only responsibilities and relationships significantly affected work stress, possibly because the study's sample was healthcare managers.

Previous research shows that work engagement generally reduces work stress. However, our study examined specifically how work stress is affected by work engagement. The findings show the need for healthcare managers to focus on responsibilities and relationships as stressors. Managers' willingness, enthusiasm, physical and mental fitness, and their determination to achieve goals all affected their reported levels of work stress. That is, engaged HMs may have lower levels of perceived stress.

\section{References}

Abeer, M. S. (2017). Organisational role stress and work engagement among nurses in a selected hospital in Cairo. American Journal of Nursing Science, 6(1), 53-62.

Antonova, E. (2016). Occupational stress, job satisfaction, and employee loyalty in hospitality industry: a comparative case study of two hotels in Russia.

Ashforth, B. E., \& Humphrey, R. H. (1995). Emotion in the Workplace: A Reappraisal. Human Relations, 48(2),

97-125.

Advance

online

publication. https://doi.org/10.1177/001872679504800201 
Aydin, İ., \& Özmutaf, N. M. (2020). Distributed leadership in healthcare: Exploring its impacts on technical quality. International Journal of Healthcare Management. Advance online publication. https://doi.org/10.1080/20479700.2020.1788342

Bailey, C., Madden, A., Alfes, K., \& Fletcher, L. (2017). The Meaning, Antecedents and Outcomes of Employee Engagement: A Narrative Synthesis. International Journal of Management Reviews, 19(1), 31-53. Advance online publication. https://doi.org/10.1111/ijmr.12077

Bakker, A. B., \& Demerouti, E. (2017). Job demands-resources theory: Taking stock and looking forward. Journal of Occupational Health Psychology, 22(3), 273-285. Advance online publication. https://doi.org/10.1037/ocp0000056

Balducci, C., Fraccaroli, F., \& Schaufeli, W. B. (2010). Psychometric Properties of the Italian Version of the Utrecht Work Engagement Scale (UWES-9). European Journal of Psychological Assessment, 26(2), 143-149. Advance online publication. https://doi.org/10.1027/1015$5759 / \mathrm{a} 000020$

Bezuidenhout, A., \& Cilliers, F. V. N. (2010). Burnout, work engagement and sense of coherence in female academics in higher-education institutions in South Africa. SA Journal of Industrial Psychology, 36(1). Advance online publication. https://doi.org/10.4102/sajip.v36i1.872

Blaug, R., Kenyon, A., \& Lekhi, R. (2007). Stress at work: A report prepared for the work foundation's principal partners. The Work Foundation.

Bochatay, N., Muller-Juge, V., Scherer, F., Cottin, G., Cullati, S., Blondon, K. S., Hudelson, P., Maître, F., Vu, N. v, Savoldelli, G. L., \& Nendaz, M. R. (2017). Are role perceptions of residents and nurses translated into action? BMC Medical Education, 17(1). https://doi.org/10.1186/s12909017-0976-2

Cannavò, M., la Torre, F., Sestili, C., la Torre, G., \& Fioravanti, M. (2019). Work Related Violence As A Predictor Of Stress And Correlated Disorders In Emergency Department Healthcare Professionals. La Clinica Terapeutica, 170(2), e110-e123. https://doi.org/10.7417/CT.2019.2120

Cavanaugh, M. A., Boswell, W. R., Roehling, M. V., \& Boudreau, J. W. (2000). An empirical examination of self-reported work stress among U.S. managers. The Journal of Applied Psychology, 85(1), 65-74. Advance online publication. https://doi.org/10.1037/00219010.85.1.65

Christian, M. S., Garza, A. S., \& Slaughter, J. E. (2011). Work Engagement: A quantitative review and test of its relations with task and contextual performance. Personnel Psychology, 64(1), 89136. Advance online publication. https://doi.org/10.1111/j.1744-6570.2010.01203.x

Cockburn, J., \& Pit, S. (1997). Prescribing behaviour in clinical practice: Patients' expectations and doctors' perceptions of patients' expectations-a questionnaire study. BMJ (Clinical Research Ed.), 315(7107), publication. https://doi.org/10.1136/bmj.315.7107.520

Advance online

Cousins, R., MacKay, C. J., Clarke, S. D., Kelly, C., Kelly, P. J., \& McCaig, R. H. (2004). 'Management Standards' work-related stress in the UK: Practical development. Work and Stress, 18(2), 113-136. Advance online publication. https://doi.org/10.1080/02678370410001734322

Cox, T., \& Cox, S. (1993). Occupational health: Control and monitoring of psychosocial and organisational hazards at work. Journal of the Royal Society of Health, 113(4), 201-205. Advance online publication. https://doi.org/10.1177/146642409311300411

Cox, T., Griffiths, A., \& Randall, R. (2003). The Handbook of Work and Health Psychology (M. J. Schabracq, J. A. M. Winnubst, \& C. L. Cooper, Eds.; Second Edition). John Wiley \& Sons Ltd. 
Crawford, E. R., Lepine, J. A., \& Rich, B. L. (2010). Linking job demands and resources to employee engagement and burnout: A theoretical extension and meta-analytic test. The Journal of Applied Psychology, 95(5), 834-848. Advance online publication. https://doi.org/10.1037/a0019364

Demerouti, E., \& Bakker, A. B. (2011). The Job Demands-Resources model: Challenges for future research. SA Journal of Industrial Psychology, 37(2). Advance online publication. https://doi.org/10.4102/sajip.v37i2.974

Dhawan, N. (2013). An Empirical Analysis of Role Stressors in Banking Sector. The Global E-Learning Journal, 2(2).

Fiabane, E., Giorgi, I., Sguazzin, C., \& Argentero, P. (2013). Work engagement and occupational stress in nurses and other healthcare workers: The role of organisational and personal factors. Journal of Clinical Nursing, 22(17-18), 2614-2624. Advance online publication. https://doi.org/10.1111/jocn.12084

Fishta, A., \& Backé, E.-M. (2015). Psychosocial stress at work and cardiovascular diseases: An overview of systematic reviews. International Archives of Occupational and Environmental Health, 88(8), 997-1014. Advance online publication. https://doi.org/10.1007/s00420-0151019-0

Ford, M. T., Matthews, R. A., Wooldridge, J. D., Mishra, V., Kakar, U. M., \& Strahan, S. R. (2014). How do occupational stressor-strain effects vary with time? A review and meta-analysis of the relevance of time lags in longitudinal studies. Work \& Stress, 28(1), 9-30. https://doi.org/10.1080/02678373.2013.877096

Fortes-Ferreira, L., Peiro, J. M., Gonzalez-Morales, M. G., \& Martin, I. (2006). Work-related stress and well-being: The roles of direct action coping and palliative coping. Scandinavian Journal of Psychology, 47(4), 293-302. https://doi.org/10.1111/j.1467-9450.2006.00519.x

Frenk, J., Chen, L., Bhutta, Z. A., Cohen, J., Crisp, N., Evans, T., Fineberg, H., Garcia, P., Ke, Y., Kelley, P., Kistnasamy, B., Meleis, A., Naylor, D., Pablos-Mendez, A., Reddy, S., Scrimshaw, S., Sepulveda, J., Serwadda, D., \& Zurayk, H. (2010). Health professionals for a new century: transforming education to strengthen health systems in an interdependent world. The Lancet, 376(9756). https://doi.org/10.1016/S0140-6736(10)61854-5

Holman, D., Johnson, S., \& O'Connor, E. (2018). Stress management interventions: Improving subjective psychological well-being in the workplace. In E. Diener, S. Oishi, \& L. Tay (Eds.), Handbook of well-being. DEF Publishers.

Huang, Y., Xu, S., Hua, J., Zhu, D., Liu, C., Hu, Y., Liu, T., \& Xu, D. (2015). Association between job strain and risk of incident stroke. Neurology, 85(19), 1648-1654. https://doi.org/10.1212/WNL.0000000000002098

Inoue, A., Kawakami, N., Tsutsumi, A., Shimazu, A., Miyaki, K., Takahashi, M., Kurioka, S., Eguchi, H., Tsuchiya, M., Enta, K., Kosugi, Y., Sakata, T., \& Totsuzaki, T. (2014). Association of Job Demands with Work Engagement of Japanese Employees: Comparison of Challenges with Hindrances (J-HOPE). PLOS ONE, 9(3), e91583. https://doi.org/10.1371/journal.pone.0091583

Kahn, R. L., Byosiere, P., \& Dunnette, M. D. (1992). Stress in organisations. In L. M. Hough (Ed.), Handbook of industrial and organisational psychology (pp. 571-650). Consulting Psychologists Press.

Karasek, R. A. (1979). Job Demands, Job Decision Latitude, and Mental Strain: Implications for Job Redesign. Administrative Science Quarterly, 24(2), 285-308. 
Karasek, R., \& Theorell, T. (1990). Healthy work: Stress, productivity and the reconstruction of working life. Basic books.

Kartal, N. (2018). Evaluating the relationship between work engagement, work alienation and work performance of healthcare professionals. International Journal of Healthcare Management, 11(3), 251-259. https://doi.org/10.1080/20479700.2018.1453969

Keashly, L., Hunter, S., \& Harvey, S. (1997). Abusive interaction and role state stressors: Relative impact on student residence assistant stress and work attitudes. Work \& Stress, 11(2), 175-185. https://doi.org/10.1080/02678379708256833

Knight, C., Patterson, M., Dawson, J., \& Brown, J. (2017). Building and sustaining work engagement a participatory action intervention to increase work engagement in nursing staff. European Journal of Work and Organizational Psychology, 26(5), 634-649. https://doi.org/10.1080/1359432X.2017.1336999

Lambert, E. G., Hogan, N. L., Camp, S. D., \& Ventura, L. A. (2006). The impact of work-family conflict on correctional staff. Criminology \& Criminal Justice, 6(4), 371-387. https://doi.org/10.1177/1748895806068572

Macey, W. H., \& Schneider, B. (2008). The Meaning of Employee Engagement. Industrial and Organisational Psychology, 1(1). https://doi.org/10.1111/j.1754-9434.2007.0002.x

Mark, G., \& Smith, A. P. (2012). Effects of occupational stress, job characteristics, coping, and attributional style on the mental health and job satisfaction of university employees. Anxiety, Stress \& Coping, 25(1), 63-78. https://doi.org/10.1080/10615806.2010.548088

Matthys, J., Elwyn, G., van Nuland, M., van Maele, G., de Sutter, A., de Meyere, M., \& Deveugele, M. (2009). Patients' ideas, concerns, and expectations (ICE) in general practice: impact on prescribing. British Journal of General Practice, 59(558), 29-36. https://doi.org/10.3399/bjgp09X394833

Mauno, S., Kinnunen, U., \& Ruokolainen, M. (2007). Job demands and resources as antecedents of work engagement: A longitudinal study. Journal of Vocational Behavior, 70(1), 149-171. https://doi.org/10.1016/j.jvb.2006.09.002

Morse, T., Fekieta, R., Rubenstein, H., Warren, N., Alexander, D., \& Wawzyniecki, P. (2008). "Doing the Heavy Lifting: Health Care Workers Take Back Their Backs." NEW SOLUTIONS: A Journal of Environmental and Occupational Health Policy, 18(2), 207-219. https://doi.org/10.2190/NS.18.2.j

Nunnally, J. C. (1967). Psychometric Theory. McGraw Hill.

Nyberg, S. T., Fransson, E. I., Heikkilä, K., Ahola, K., Alfredsson, L., Bjorner, J. B., Borritz, M., Burr, H., Dragano, N., Goldberg, M., Hamer, M., Jokela, M., Knutsson, A., Koskenvuo, M., Koskinen, A., Kouvonen, A., Leineweber, C., Madsen, I. E. H., Magnusson Hanson, L. L., ... Kivimäki, M. (2014). Job Strain as a Risk Factor for Type 2 Diabetes: A Pooled Analysis of 124,808 Men and Women. Diabetes Care, 37(8), 2268-2275. https://doi.org/10.2337/dc13-2936

Paunonen, S. v., \& Ashton, M. C. (2001). Big Five factors and facets and the prediction of behaviour. Journal of Personality and Social Psychology, 81(3), 524. https://doi.org/10.1037/00223514.81.3.524

Rick, J., \& Briner, R. B. (2000). Psychosocial Risk Assessment: Problems and Prospects. Occupational Medicine, 50(5), 310-314. https://doi.org/10.1093/occmed/50.5.310

Schaufeli, W. B., Salanova, M., González-romá, V., \& Bakker, A. B. (2002). The measurement of engagement and burnout: A two sample confirmatory factor analytic approach. Journal of Happiness Studies, 3(1), 293-315. https://doi.org/10.1023/A:1015630930326 
Schaufeli, W., \& Salanova, M. (2007). Work engagement: An emerging psychological concept and its implications for organisations. In S. W. Gilliland, D. D. Steiner, \& D. P. Skarlicki (Eds.), Research in social issues in management (Volume 5): Managing social and ethical issues in organisations (Vol. 5, pp. 135-177). Information Age Publishers.

Shaw, J. B., Fields, M. W., Thacker, J. W., \& Fisher, C. D. (1992). The availability of personal and external coping resources: their impact on job stress and employee attitudes during organisational restructuring (No. 25).

Spence Laschinger, H. K., Finegan, J., Shamian, J., \& Almost, J. (2001). Testing Karasek's demandscontrol model in restructured healthcare settings: effects of job strain on staff nurses' quality of work life. ONA: The Journal of Nursing Administration, 31(5), 233-243. https://doi.org/10.1097/00005110-200105000-00003

Stansfeld, S., \& Candy, B. (2006). Psychosocial work environment and mental health-a meta-analytic review. Scandinavian Journal of Work, Environment \& Health, 32(6), 443-462. https://doi.org/10.5271/sjweh.1050

Sutherland, V. J., \& Cooper, C. L. (1990). Psychology and health series, Vol. 5. Understanding stress: A psychological perspective for health professionals (1st ed.). Chapman \& Hall.

Taouk, Y., Spittal, M. J., Milner, A. J., \& LaMontagne, A. D. (2020). All-cause mortality and the timevarying effects of psychosocial work stressors: A retrospective cohort study using the HILDA $\begin{array}{lllll}\text { survey. Social Science } \& \quad \text { Medicine, } & 266,\end{array}$ https://doi.org/10.1016/j.socscimed.2020.113452

Timms, C., Brough, P., O’Driscoll, M., Kalliath, T., Siu, O. L., Sit, C., \& Lo, D. (2015). Flexible work arrangements, work engagement, turnover intentions and psychological health. Asia Pacific Journal of Human Resources, 53(1), 490-510. https://doi.org/10.1111/1744-7941.12030

Tutuncu, O., Cobaner, A. A., Guzelgoz, O., Cetin, A., Malkoc, M., \& Mollahaliloglu, S. (2014). The effects of health transformation program on patient-healthcare personnel communication and interaction in Turkey. Quality \& Quantity, 48(6), 3433-3446. https://doi.org/10.1007/s11135-0139965-7

Unsworth, K. L., \& Mason, C. M. (2012). Help yourself: The mechanisms through which a selfleadership intervention influences strain. Journal of Occupational Health Psychology, 17(2), 112. https://doi.org/10.1037/a0026857

van Bogaert, P., Adriaenssens, J., Dilles, T., Martens, D., van Rompaey, B., \& Timmermans, O. (2014). Impact of role-, job- and organisational characteristics on Nursing Unit Managers' work-related stress and well-being. Journal of Advanced Nursing, 70(11), 2622-2633. https://doi.org/10.1111/jan.12449

vander Elst, T., Cavents, C., Daneels, K., Johannik, K., Baillien, E., van den Broeck, A., \& Godderis, L. (2016). Job demands-resources predicting burnout and work engagement among Belgian home health care nurses: A cross-sectional study. Nursing Outlook, 64(6), 542-556. https://doi.org/10.1016/j.outlook.2016.06.004

van Dorssen-Boog, P., de Jong, J., Veld, M., \& van Vuuren, T. (2020). Self-Leadership Among Healthcare Workers: A Mediator for the Effects of Job Autonomy on Work Engagement and Health. Frontiers in Psychology, 11, 1420. https://doi.org/10.3389/fpsyg.2020.01420

Wallace, J. E., Lemaire, J. B., \& Ghali, W. A. (2009). Physician wellness: a missing quality indicator. The Lancet, 374(9702), 1714-1721. https://doi.org/10.1016/S0140-6736(09)61424-0 
Weigl, M., Müller, A., Vincent, C., Angerer, P., \& Sevdalis, N. (2012). The association of workflow interruptions and hospital doctors' workload: a prospective observational study. BMJ Quality \& Safety, 21(5), 399-407. https://doi.org/10.1136/bmjqs-2011-000188

The research paper passed the review process. | Received: August 27, 2021; Revised: October 25, 2021; Accepted: November 16, 2021; Pre-published online: January 18, 2022; Published in the regular issue: September 19, 2022. 